Check for updates

The BMJ

fgodlee@bmi.com Follow Fiona on Twitter @fgodlee

Cite this as: $B M / 2021 ; 373: n 1035$ http://dx.doi.org/10.1136/bmj.n1035 Published: 22 April 2021

\title{
How do we tackle structural racism and inequality?
}

\section{Fiona Godlee editor in chief}

Two separate events in recent weeks have focused minds on the issue of structural racism. The first was last month's suspension of JAMA's editor in chief, after widespread condemnation of a podcast that sought to press the view that structural racism in US healthcare didn't exist. ${ }^{1}$ The second was this month's public outcry about the Sewell report, commissioned by the UK government, which concluded that structural racism in the UK did not exist. ${ }^{23}$

If there is any doubt in people's minds about the existence of structural racism, let alone its damaging effects on health, several recent $B M J$ articles should help. The BMA's Chaand Nagpaul leads the charge. ${ }^{4}$ Structural race inequality is a major factor affecting outcomes and life chances for many in the UK, he says. While the Sewell report lays claim to the NHS as a success story because of the number of ethnic minority staff it employs, Nagpaul highlights the disadvantage and discrimination faced by ethnic minority doctors, evidenced by reports of bullying and harassment, unwillingness to raise concerns, increased risk of referral to the General Medical Council, differential attainment, and the ethnicity pay gap. These serious charges are, sadly, confirmed in the recent "shocking but not surprising" report into racism, sexism, and homophobia at the Royal College of Surgeons. ${ }^{5}$

The pandemic has served only to magnify the damage that structural racism does to health, with worse outcomes among ethnic minority groups because of their riskier occupations and worse housing, finances, and access to healthcare. Testing and vaccination programmes have sharpened this dire convergence of risk factors: only people who can afford it will come forward for tests and be able to self-isolate; and most vaccination programmes favour people with private transport and flexible jobs. ${ }^{6}$ The ultimate danger is that covid will entrench these inequalities and become a disease of poverty. ${ }^{7}$

What can be done to tackle these race inequalities? The NHS Race and Health Observatory was launched last year after The BMJ highlighted the sustained impact of racism in medicine (bmj.com/racism-inmedicine). Its focus is on the "causes of causes" of health inequalities, looking for the reasons that ethnic minorities are more at risk of poor health outcomes and less well served by healthcare. ${ }^{8}$ Tackling health inequalities is a job that the UK's public health professionals are eager and ready to take on, ${ }^{9}$ although the country's proposed new structures seem designed to hinder rather than help. ${ }^{10} 11$

Healthcare organisations, including medical journals, have a long way to go before they can be part of the solution rather than the continuing problem. ${ }^{12} \mathrm{We}$ know this is equally true of The BMJ, and we are starting that journey. We are actively reviewing the diversity of our editorial teams and advisory boards; we have joined the Journalism Diversity Fund ${ }^{13}$ and the Royal Society of Chemistry initiative to make research publishing more inclusive and diverse ${ }^{14}$; and we are reviewing our policies on publishing research into racial inequalities in health. We will report on our progress and welcome your views.

Tanne JH. JAMA editor is placed on leave after controversial podcast on structural racism. BM/2021;372:n851.

doi: 10.1136/bmj.n851 pmid: 33781996

2 lacobucci G. What did the Commission on Race and Ethnic Disparities say on health?BMJ2021;373:n943. doi: 10.1136/bmj.n943 pmid: 33836999

3 Razai MS, Majeed A, Esmail A. Structural racism is a fundamental cause and driver of ethnic disparities in health. BMJ Opinion. 31 Mar 2021. https://blogs.bmj.com/bmj/2021/03/31/structural-racism-is-a-fundamentalcause-and-driver-of-ethnic-disparities-in-health.

$4 \quad$ Nagpaul C. The lived experience of many ethnic minority doctors is not an equality success story. BMJ Opinion. 16 Apr 2021. https://blogs.bmj.com/bmj/2021/04/16/chaand-nagpaul-the-lived-experience-of-many-ethnic-minority-doctors-is-not-an-equality-success-story.

5 Mapara R, Munro C, Ajekigbe M, McLachlan G. Sexism, racism, and homophobia at the Royal College of Surgeons of England. BMJ 2021;373:n998. doi: 10.1136/bmj.n998 pmid: 33879524

6 Menezes NP, Rucinski K, Baral S. Covid-19 testing programs: who benefits? BMJ Opinion. 16 Apr 2021. https://blogs.bmj.com/bmj/2021/04/16/covid19-testing-programs-who-benefits.

7 Pagel C. A very real danger that covid-19 will become entrenched as a disease of poverty. BMJ Opinion. 9 Apr 2021. https://blogs.bmi.com/bmi/2021/04/09/christina-pagel-a-very-real-dangerthat-covid-19-will-become-entrenched-as-a-disease-of-poverty.

8 Jeraj S. Doing the work to end health inequalities caused by systemic racism. BMJ 2021;373:n821. doi: 10.1136/bmj.n821 pmid: 33863708

9 Wilkinson E. What the new Health Security Agency means for public health. BMJ 2021;373:n996doi: 10.1136/bmj.n996.

10 Scally G. A new public health body for the UK. BMJ2021;373:n875. doi: 10.1136/bmj.n875 pmid: 33795215

11 Oliver D. David Oliver: Renaming government agencies won't improve population health. BMJ2021;373:n1004doi: 10.1136/bmj.n1004.

12 Gopal DP, Rao M. Playing hide and seek with structural racism. BMJ 2021;373:n988doi: 10.1136/bmj.n988.

13 Journalism Diversity Fund. https://www.journalismdiversityfund.com.

14 Royal Society of Chemistry. World-leading publishers join us in commitment to make research publishing more inclusive and diverse. https://www.rsc.org/news-events/articles/2020/jun/publishers-join-us-inid-commitment. 